\title{
Undocumented Speakers and Freedom of Speech: A Relatively Uncontroversial Approach
}

\author{
R. George Wright ${ }^{*}$
}

TABLE OF CONTENTS

I. INTRODUCTION

II. STANDING AND SUBSTANTIVE RIGHTS TO HEAR THE SPEECH OF OTHERS...502

III. RESTRICTIONS ON THE SPEECH OF UNDOCUMENTED PERSONS AS IMPAIRING THE BASIC PURPOSES OF FREEDOM OF SPEECH IN GENERAL .....506

IV. DO THE EQual Protection RightS OF All PERSONS UNCONTROVERSIALLY ADVANCE THE FREE SPEECH ARGUMENT?

V. CONCLUSION

\section{INTRODUCTION}

The question of federal constitutional free speech rights for undocumented speakers is generally unexplored in case law ${ }^{1}$ and in law review literature. ${ }^{2}$ The underdevelopment of case law and scholarship in this area likely reflects an analytical misstep. As it turns out, the analysis can be crucially misconceived if it is focused narrowly and directly on the claimed free speech rights of undocumented speakers themselves.

In contrast, the analysis below recognizes and develops the point that free speech is often not simply a matter of speakers themselves, or even the content of their speech, the conditions under which they speak, and the restrictions under which speakers may labor. Free speech is not reducible to these elements or any combination thereof.

Crucially, free speech rights are what we may call complementary, or "inherently relational." In any given context, free speech rights are held jointly and severally by actual or potentially willing speakers and, equally, by actual or potentially willing

\footnotetext{
* Lawrence A. Jegen Professor of Law, Indiana University School of Law - Indianapolis. The author hereby thanks Maria Lopez, Jennifer Ekblaw, and Rachel Anne Scherer.

1. For as close as the case holdings apparently come, see a number of the authorities cited infra Part IV.

2. For an extremely valuable but relatively narrow treatment focusing on "extraordinary speech" of undocumented immigrants to law enforcement officials conceming primarily health and safety code violations, and under the right to "petition the Government for redress of grievances," see generally Michael J. Wishnie, Immigrants and the Right to Petition, 78 N.Y.U. L. REV. 667, 667 (2003). For a sense of the scarcity of free speech decisions and free speech scholarship focusing even on the broader class of all immigrants, documented or undocumented, see $i d$. at 714-15.
} 
listeners. Those actual or willing listeners, readers, or communication recipients are the actual or potential audience for the speech in question.

Free speech rights are in this sense essentially complementary, or inherently relational. They are held jointly by speakers and potential willing speakers and by listeners and potential willing listeners, in equal measure. But for our purposes, it is vital to notice that these complementary or relational rights may typically be exercised severally, or in the ability of an audience to listen to a particular speaker. More directly relevant for our purposes, a potential audience member may properly object to restrictions on the speech of otherwise willing speakers. ${ }^{3}$

Thus, where potential audience members hold certain free speech rights, those rights may carry practical implications for the way the law should treat any willing potential speakers the potential audience wishes to hear. The inherent complementarity of free speech rights means that in certain cases, audience or potential audience free speech rights will require what we might call pragmatic or de facto speech rights, of whatever strength and scope, for all those persons the potential audience wishes to hear.

More specifically, and most directly relevant to our concerns, there will be many instances in which fully enfranchised adult United States citizen-voters and documented aliens will wish to hear, on subjects of public interest, from some or all undocumented persons within the United States. Merely for the sake of simplicity, we shall refer hereafter to those who wish to hear from undocumented persons as citizen-voters.

On some narrow or technical issues, it may be reasonable to wish to listen only to some combination of documented immigrants, economists, sociologists, politicians, advocates, journalists, think-tanks, social workers, or other technical experts.

But some citizen-voters will inevitably wish to hear from some or all undocumented persons on a wide range of public issues. The point of listening to some range of undocumented persons would not be to automatically override the voices of documented aliens, of social scientists, or of citizens in general. The idea would instead normally be to consider and weigh the distinctive contribution to the discussion that the range of undocumented alien perspectives might bring.

Such an approach would be perfectly sensible as a matter of the general doctrinal rights of willing audience members to hear potentially willing speakers. ${ }^{4}$ And such an approach would also be consistent with the underlying logic of the values and purposes of freedom of speech in the first place. ${ }^{5}$ It is perfectly defensible to believe that traditionally cited free speech values, including the pursuit of truth and the effective functioning of political democracy, among other such values, ${ }^{6}$ may be best
3. See infra Part II.
4. See infra Part II.
5. See infra Part III.
6. See infra Part III. 
served by listening to any and all undocumented speakers, of whatever viewpoint, on a broad range of issues.

In such cases, the uncontroversial free speech rights driving the analysis are those of the willing audience. The idea of the citizen-voter as bearing free speech rights is beyond question. And the free speech rights of a sub-set of citizen-voters, as a potential audience, may well be violated if the undocumented speakers, that the potential audience wishes to hear, are discouraged by the government from speaking. ${ }^{7}$ Realistically, even after-the-fact sanctions on undocumented speakers, whether in the form of technical punishment or not, may well discourage further speech. ${ }^{8}$

There may well be cases in which the clear and uncontested free speech rights of citizen-voters are substantially burdened or simply violated by government action, of whatever sort, that inhibits or somehow restricts the speech of undocumented persons. 9 In all such cases, the inherent relationality of free speech operates, in effect, to confer certain "pragmatic" free speech rights on any or all undocumented persons any citizen-voter may wish to hear. ${ }^{10}$

This would follow regardless of the preferences of any particular citizen-voter. Any citizen-voter may wish to hear from some or all undocumented persons, on a narrower or broader range of issues, perhaps from some specific viewpoints, or not. Some citizen-voters may wish to hear what amounts to a monologue from undocumented speakers, while others may prefer to engage in dialogue or some more pluralistic discussion. Free speech rights can be grounded in a potential willing audience of as few as one person. But in the aggregate, when the preferences and rights of all such citizen-voters are totaled up, the net effect will inevitably be, in practical effect, what amounts to a substantial and robust set of free speech rights for undocumented persons in general.

More precisely, the free speech rights of undocumented speakers do not arise and disappear in immediate correspondence with any particular citizen-voter's wish to hear or not hear from such undocumented speakers. The free speech right of undocumented speakers may predate or anticipate a likely future expression of interest by citizen-voters and survive any temporary abeyance of such interest. The free speech rights of undocumented speakers may thus be based on undocumented speech as an available resource, as distinct from merely an on-demand service.

7. See infra Part II.

8. See infra Part II.

9. See infra Part IL

10. See infra Part II While free speech rights generally do not require limitless government subsidization, they also set some limits to governments' authority to discourage speech for particular reasons. See, e.g., Forsyth County, Ga. v. Nationalist Movement, 505 U.S. 123, 130 (1992) ("[G]overnment ... may impose a permit requirement on those wishing to hold a march, parade, or rally... Such a scheme, however, must meet certain constitutional requirements.") (citations omitted). 
These "pragmatic" free speech rights held by undocumented persons are no less real and substantial even if any particular undocumented person chooses not to speak. Correspondingly, citizen-voters do not generally have a free speech right to compel undocumented persons to speak publicly if the latter would prefer not to speak. And it is also clear that the "practical" free speech rights of undocumented persons remain in effect if some, or even many, citizen-voters would prefer that they not speak. ${ }^{11}$ After all, a citizen-voter's wish to hear a speaker or message, in an appropriate time, place, and manner, is generally not subject to "veto" by some objecting party with the ability to avoid listening. ${ }^{12}$

In any event, the argument below is intended to clarify, elaborate upon, and otherwise strengthen this "relational" approach to undocumented speakers and freedom of speech. As we shall also see, other approaches to the problem of undocumented speakers are certainly possible, but they bring with them their own limitations, complications, and controversies. ${ }^{13}$

\section{STANDING AND SUBSTANTIVE RIGHTS TO HEAR THE SPEECH OF OTHERS}

We may start with the general principle that the constitutionally mandated elements of standing and the prudential or judge-made aspects of standing are commonly interpreted generously in the free speech area. ${ }^{14}$ This general principle

11. There are important limits on even the government's rights to compel speech by private parties. See, e.g., Wooley v. Maynard, 430 U.S. 705,714 (1977); W. Va. State Bd. of Educ. v. Barnette, 319 U.S. 624, 633-34 (1943).

12. For a discussion of limits on a "heckler's veto" of disfavored speech, see Terminiello v. Chicago, 337 U.S. 1, 45 (1949).

13. See infra Part IV.

14. See, e.g., Virginia v. Am. Booksellers Ass'n, 484 U.S. 383, $392-93$ (1988) (showing concern for a chilling effect on speech unless prudential standing rules were relaxed in a facial challenge case); Va. State. Bd. of Pharmacy v. Va. Citizens Consumer Council, 425 U.S. 748, 756-57 (1976) (holding that would-be-listeners have standing to bring a first amendment claim to hear even pure commercial speech from a would-be-speaker); Lamont v. Postmaster Gen., 381 U.S. 301, 308 (1965) (Brennan, J., concurring) (recognizing that the audience has First Amendment standing to sue, given the importance of openness of public discussion); Kan. Judicial Rev. v. Stout, 519 F.3d 1107, 1115 (10th Cir. 2008); King v. Fed. Bureau of Prisons, 415 F.3d 634, 638 (7th Cir. 2005); Spargo v. N.Y. State Comm'n on Judicial Conduct, 351 F.3d 65, 83-84 (2d Cir. 2003); Essence, Inc. v. City of Federal Hts., 285 F.3d 1272, 1287 n.13 (10th Cir. 2002) (First Amendment standing available for litigant whose rights are "intertwined" with those of a third party non-litigant); Pittman v. Cole, 267 F.3d 1269, 1283 (11th Cir. 2001) (applying First Amendment injury requirement loosely); ACLU v. Johnson, 194 F.3d 1149, 1154-55 (10th Cir. 1999) (applying ripeness requirement loosely in First Amendment cases); Perry v. Village of Arlington Hts., 186 F.3d 826, 829-30 (7th Cir. 1999) (requiring plaintiffs to show the existence of a willing potential speaker at the relevant time); U.S. West, Inc. v. Fed. Commc'ns Comm'n, 182 F.3d 1224, 1232 (10th Cir. 1999); Ruocchio v. United Transp. Union, 181 F.3d 376, 385 (3d Cir. 1999) (noting that the standing doctrine is generally to be expansively interpreted in First Amendment cases); Duwe v. Alexander, 490 F. Supp. 2d 968, 972 (W.D. Wis. 2007) ("[P]laintiffs have demonstrated ... that there are willing speakers who support 
applies across a range of aspects of standing and related gate-keeping doctrines. ${ }^{15}$ This principle reflects the importance to our society of free, open, and unconstrained debate in general, and the value of dispelling any potential "chill" or inhibition of such debate as expeditiously as possible. ${ }^{16}$

On the merits, it is well established, with impeccable logic, that freedom of speech generally is in large measure a matter of the rights of listeners and would-be listeners. Crucially, the rights of listeners are not simply derivative of independent rights of speakers: "More importantly, the right to receive ideas is a necessary predicate to the recipient's meaningful exercise of his own rights of speech, press, and political freedom." presupposes a willing speaker." is to the communication, to its source and to its recipients both."19

Crucially for our purposes, the Court has denied any general principle that "freedom of speech may be abridged when the speaker's listeners could come by his message by some other means. .. . Nor have we recognized any such limitation on the independent right of the listener to receive the information sought to be communicated." 20 Thus it may be impermissible for the government to suppress the ability of undocumented persons to speak even if the views and emotions of undocumented persons could always be obtained from other sources.

Our point is again not that undocumented persons have free speech rights, and that violation of those rights also burdens the free speech rights of interested citizenvoters. It is instead that citizen-voters unquestionably possess the free speech rights of listeners or information-seekers and would-be speech recipients, and that these rights will often, as a practical matter, require pragmatic free speech rights of undocumented speakers, particularly on matters of public import ${ }^{21}$ on which at least

their standing...."); Deida v. City of Milwaukee, 192 F. Supp. 2d 899, 904-05 (E.D. Wis. 2002); Snyder v. Bd. of Trustees of Univ. of Ill., 286 F. Supp. 927, 932 (N.D. Ill. 1968) (three judge court) ("[W]e see no reason why the audience should be precluded from asserting their interests, merely because the speaker is disinclined to wage a legal battle.") (citation omitted).

15. See cases cited supra note 14.

16. See cases cited supra note 14, in particular Lamont, 381 U.S. at 308 (Brennan, J., concurring).

17. Bd. of Educ. v. Pico, 457 U.S. 853, 867 (1982) (plurality opinion). Pico, a public school library book removal case, relies in part on First Nat'l Bank of Boston v. Bellotti, 435 U.S. 765, 783 (1978) (referring to a First Amendment right of "public access to discussion, debate, and the dissemination of information and ideas").

18. Va. State Bd. of Pharmacy, 425 U.S. at 756.

19. Id. at 756-57 (citing Procunier v. Martinez, 416 U.S. 396, 408-09 (1974) (explaining the lack of any necessity to consider any free speech rights of prison inmates themselves, given the free speech rights of non-inmate correspondents)).

20. Va. State Bd. of Pharmacy, 425 U.S. at 757 n. 15.

21. For the specially protected constitutional status of what the Court refers to as speech on matters of public interest, see, for example, Garcetti v. Ceballos, 547 U.S. 410, 417-18 (2006) (in the 
some citizen-voters will wish to be broadly informed. More concisely, guaranteeing speech rights to undocumented persons is a matter of making some citizen-voter free speech rights real and meaningful, in light of the basic purposes of the institution of freedom of speech. $^{22}$

This does not mean that undocumented persons are not properly subject to valid immigration law and process whenever the free speech rights of citizen-voters would be adversely affected thereby. ${ }^{23}$ It would be odd if immigration law, or prison law for that matter, ${ }^{24}$ were fundamentally driven by, and shaped even in detail by, the free speech rights of citizen-voters.

But it would be equally odd to claim that immigration law, or prison law, has absolutely no effect on the nature, meaning, and value of citizen-voter free speech rights. Immigration law cannot be entirely insulated from free speech law. Imagine, hypothetically, an immigration statute that prohibits anyone subject to a final, unappealed order of deportation from communicating about their case, or any other matter of public interest, with any journalist, publisher, or any other media. We need not say that such a statute would be facially invalid, or should be denied application in any particular case. And we need not assume any deportee free speech rights. Our argument here is merely that in such a case, the free speech rights of the media, and of the media's audiences, would be implicated, and should properly be taken into account, to one degree or another, in denying any free speech rights of the deportees.

As a matter of realistic necessity, audience free speech rights in such cases would imply practical free speech rights, of whatever strength and scope, on the part of those subject to final orders of deportation. This logic would of course apply at least as forcefully to undocumented persons not subject to such deportation orders, or not yet even informally determined to lack documentation.

It is thus certainly not that any free speech interest must outweigh or trump any immigration policy with which such an interest may be in tension. Rather, free speech interests of both speakers and audiences ${ }^{25}$ are often plainly of constitutionally

context of public employee free speech rights); Dun \& Bradstreet, Inc. v. Greenmoss Builders, 472 U.S. 749, 751 (1985) (in the context of free speech limits on libel law); See also R. George Wright, Speech on Matters of Public Interest and Concern, 37 DEPAUL L. REV. 27, 27 (1987).

22. See infra Part III.

23. See Kleindienst v. Mandel, 408 U.S. 753, 768-69 (1972) (Belgian Marxist denied temporary nonimmigrant visa on grounds of advocacy of "world communism," despite the existence of citizens inviting his domestic presence for an academic conference).

24. See Procunier, 416 U.S. at 398.

25. For further endorsement of the idea of free speech rights of audiences or potential audiences, see, for example, Red Lion Broadcasting v. Fed. Commc'n Comm'n, 395 U.S. 367, 390 (1969) (stating that the rights of television news and editorial audiences are paramount over broadcasters in right-of-reply context); Stanley v. Georgia, 394 U.S. 557, 564 (1969) (citing a string of cases in support of freedom of speech protecting "the right to receive information and ideas" in the context of private possession of allegedly obscene materials); Lamont v. Postmaster General, 381 U.S. 301, 305-07 (1965) (discussing a response card system regarding communist-oriented postal 
fundamental importance, and must be taken into proper account as far as those interests extend.

It is important to note the range of circumstances under which the audience rights of citizen-voters might be impaired by government policies affecting undocumented persons. A wide range of government actions and policies, at various levels, may operate to "chill" undocumented speech, whether the person's status as undocumented has been formally established or brought to official attention or not. Certainly, the fear of deportation may suffice to inhibit speech by undocumented persons, whether the practical sanction of deportation would reflect official disagreement with the content of the undocumented person's speech or not. ${ }^{26}$

Deportation, certainly, is generally considered a civil as opposed to a criminal process. ${ }^{27}$ Thus deportation typically does not qualify as a punishment, ${ }^{28}$ no matter how "burdensome and severe"29 deportation may be for the alien. But the risk of deportation can certainly suffice to deter or inhibit speech. Government actions or policies need not even be formal, let alone punitive in status, to inhibit free speech. ${ }^{30}$ And if the undocumented person's speech is "chilled," the interested citizen-voter does not hear it.

As a leading expert has written of all categories of aliens in general, "[b]ecause deportation is usually seen as a drastic penalty (at times, perhaps, more harsh than imprisonment), aliens are likely to forgo speech condemned by the deportation provisions. The immigration status therefore chills the exercise of First Amendment

mailings as burdening the addressee's free speech rights and the general public interest in "uninhibited, robust, and wide-open" public discussion and debate); King v. Fed. Bureau of Prisoners, 415 F.3d 634, 638 (7th Cir. 2005) (noting prison's refusal to allow prisoner to obtain a book on computer programming and stating, "[f]reedom of speech is not merely freedom to speak; it is also freedom to read'); U.S. West, Inc. v. Fed. Commc'ns Comm'n, 182 F.3d 1224, 1232 (10th Cir. 1999); Monteiro v. Tempe Union High School Dist., 158 F.3d 1022, 1027 \& n.5 (9th Cir. 1998) (citing Pico plurality in context of public school mandating an allegedly discriminatory reading assignment); City of Watseka v. Illinois Pub. Action Council, 796 F.2d 1547, 1574 (7th Cir. 1986) (Coffey, J., dissenting, in political canvassing restriction case); Kreimer v. Bureau of Police for Town of Morristown, 958 F.2d 1242, 1250-55 (3d Cir. 1992) (homeless individual challenging public library's access and behavior policies); Snyder v. Bd. of Trustees of Univ. of Ill., 286 F. Supp. 927, 931-32 (1968) (concerning a statute prohibiting university facility access to allegedly subversive organizations). Finally, in the "company town" context, see Marsh v. Alabama, 326 U.S. 501, 505-06 (1946).

26. See T. Alexander Aleinikoff, Federal Regulation of Aliens and the Constitution, 83 AM. J. INT'L L. 862, 868 (1989). See generally R. George Wright, Content-Based and Content-Neutral Regulation of Speech: The Limitations of a Common Distinction, 60 U. MIAMI L. REv. 333 (2006).

27. See Harisiades v. Shaughnessy, 342 U.S. 580, 594 (1952).

28. See id. at 59495 (quoting Mahler v. Eby, 264 U.S. 32, 39 (1924)).

29. See id.

30. The classic case, outside the immigration context, on informal censorship through informal governmental sanctions is Bantam Books v. Sullivan, 372 U.S. 58, 66-67 (1963). 
rights outside the immigration context., 31 And it seems fair to assume that what is true for aliens in general in this respect will be typically no less true for undocumented persons in particular.

\section{RESTRICTIONS ON THE SPEECH OF UNDOCUMENTED PERSONS AS IMPAIRING THE BASIC PURPOSES OF FREEDOM OF SPEECH IN GENERAL}

As we have seen, recognition of "pragmatic" free speech rights of undocumented persons, for the sake most fundamentally of the free speech rights of citizen-voters, is more than a matter of narrow legal doctrine. The idea is built into the basic logical structure of inherently related and mutually dependent speakers and audiences. ${ }^{32}$

But the logic of "pragmatic" or derivative free speech rights for undocumented persons extends, more deeply, into the level of the basic reasons for constitutionally protecting freedom of speech. Freedom of speech is not an end in itself. It is protected for certain reasons. ${ }^{33}$ The idea is that freedom of speech honors certain values or, even more importantly, tends especially to actually promote certain aims, values, goals and achievements. ${ }^{34}$

Several such aims are commonly cited. We shall focus, briefly, on those free speech aims that seem least controversial and most important in accounting for the link between the uncontroversial free speech rights of citizen-voters and the realistically implicated "pragmatic" free speech rights of undocumented persons who might be sought out by some citizen-voters as sources of information and insight.

Perhaps most obviously, freedom of speech can distinctively contribute to the optimal functioning of a fully democratic, open, responsive, participatory government and administration, at all levels. ${ }^{35}$ Under this rubric we may include some reasonably

31. See Aleinikoff, supra note 26 , at 868 . For a longer and more particular discussion, see Wishnie, supra note 2.

32. See supra Parts I and II.

33. For discussion, see, for example, THOMAS I. EMERSON, THE SYSTEM OF FREEDOM OF EXPRESSION 6-9 (1970); Kent Greenawalt, Free Speech Justifications, 89 COLUM. L. REV. 119, 119 20 (1989).

34. See, e.g., EMERSON, supra note 33, at 6-9; Greenawalt, supra note 33, at 119-20.

35. For discussions of the important role that promoting democracy plays in the justification of special constitutional protection for freedom of speech, see, for example, OWEN M. FISS, THE IRONY OF FrEE SPEECH 2 (1996) (discussing the "First Amendment as a protection of popular sovereignty"); ALEXANDER MEIKLEJOHN, POLITCAL FREEDOM: THE CONSTTIUTIONAL POWERS OF THE PEOPLE 27, 75 (1960) (1948) (first amendment primarily aimed at the goal that "all the citizens shall, so far as possible, understand the issues which bear upon our common life"). Notice in particular how Professor Meiklejohn's controversial limitation concerning political understanding by citizens does not tend to undermine, and in fact is compatible with, our approach herein. Realistically, citizens' full understanding of public issues requires unconstrained speech on such matters by undocumented persons.

For a general critique of Meiklejohn's emphases, see STEVEN H. SHIFFrIN, THE FIRST AMENDMENT, DEMOCRACY, AND ROMANCE 47-49 (1990); Robert Post, Meiklejohn's Mistake: 
stable yet adaptive balance between fundamental policy continuities and institutional, cultural, and policy change. ${ }^{36}$

The importance of broadly unconstrained public discussions to a genuinely open democratic government has been recognized not only by theorists across the political spectrum, ${ }^{37}$ but by the Supreme Court itself. ${ }^{38}$ The Court has emphasized the role of the First Amendment "in affording the public access to discussion, debate, and the dissemination of information and ideas. ${ }^{, 39}$ Classically, Justice Brandeis asserted that "public discussion is a political duty," that "it is hazardous to discourage thought,",1 and that the Framers believed "in the power of reason as applied through public discussion."A2

The Court adopted a number of Justice Brandeis' themes in the classic public official libel case of New York Times v. Sullivan. ${ }^{43}$ Justice Brennan, for the Court in Sullivan, famously recognized our "profound national commitment to the principle that debate on public issues should be uninhibited, robust, and wide-open." ${ }^{4}$ The First Amendment significance and the practical value of promoting the broadest, most

Individual Autonomy and the Reform of Public Discourse, 64 U. COLO. L. REV. 1109, 1117-18 (1993). For further discussion of the promotion of democracy as a crucial free speech value, see, for example, Vincent Blasi, The Checking Value in First Amendment Theory, 1977 AM. B. FouND. RES. J. 521, 574 (1977); Robert H. Bork, Neutral Principles and Some First Amendment Problems, 47 IND. L.J. 1, 23 (1971); William J. Brennan, Jr., The Supreme Court and the Meiklejohn Interpretation of the First Amendment, 79 HARV. L. REv. 1, 1, 16-17 (1965); Greenawalt, supra note 33, at 145 (citing ERIC BARENDT, FREEDOM OF SPEECH 23 (1985)). See generally ZECHARIAH CHAFEE JR., FREE SPEECH IN THE UNITED STATES (Harvard Press ed. 1967) (1941).

36. For discussion, see, for example, EMERSON, supra note 33, at 7; Blasi, supra note 35, at 574; Greenawalt, supra note 33, at 141 (referring to the public interest in "interest accommodation and social stability"). To the extent we rely herein on the particular free speech value of interest accommodation and social stability, we do not wish to beg our primary question by merely assuming that any proper accommodation of the interests of undocumented persons would grant such persons general free speech rights within United States territory.

37. See authorities cited supra notes 34-36.

38. See authorities cited supra notes 34-36.

39. Bd. of Educ. v. Pico, 457 U.S. 853, 866 (1982) (plurality opinion) (quoting First Nat'l Bank of Boston v. Bellotti, 435 U.S. 765, 783 (1978)).

40. Whitney v. California, 274 U.S. 357, 375 (1927) (Brandeis, J., concurring) (overruled in part on other grounds, Brandenburg v. Ohio, 395 U.S. 444, 449 (1969)).

41. Whitney, 274 U.S. at 375.

42. Id. at $375-76$.

43. 376 U.S. 254, 270 (1964) (quoting Whitney, 274 U.S. at 375-76).

44. Sullivan, 376 U.S. at $270-71$ (citing Terminiello v. Chicago, 337 U.S. 1, 4 (1949)). This language from Sullivan has been widely quoted with approval, including in cases such as Fed. Election Comm'n v. Wis. Right to Life, 551 U.S. 449, 467-68 (2007); Bartnicki v. Vopper, 532 U.S. 514, 534-35 (2001); id. ("AA] stranger's illegal conduct does not suffice to remove the First Amendment shield from speech about a matter of public concern."); Waters v. Churchill, 511 U.S. 661, 672 (1994); Milkovich v. Lorain Journal Co., 497 U.S. 1, 20 (1990); NAACP v. Claiborne Hardware Co., 458 U.S. 886, 913 (1982). 
inclusive public discussion and dissemination of ideas has since been recognized in a variety of contexts. ${ }^{45}$

This is not to claim that in these contexts the Court has recognized and endorsed the free speech rights of undocumented persons in particular. That judicial fact does not undermine our argument; it merely provides the occasion for, or makes necessary, our argument herein. "[U]ninhibited, robust, and wide-open" ${ }^{, 46}$ public discussion, even among citizen-voters alone, requires that appropriate weight be given to the various preferences among some citizen-voters for access to a broad range of undocumented persons' willingly expressed perspectives, including their experiences and views on a broad range of public issues.

Those citizen-voters who are indifferent or hostile to such expressions have the classic remedy of not being compelled to listen. ${ }^{47}$ As the Court observed in Cohen v. California,

The ability of government, consonant with the Constitution, to shut off discourse solely to protect others from hearing it is ... dependent upon a showing that substantial privacy interests are being invaded in an essentially intolerable manner. Any broader view of this authority would effectively empower a majority to silence dissidents simply as a matter of personal predilection. ${ }^{48}$

Of course, our focus herein is not precisely on the silencing of undocumented persons, but on the silencing of their invited discourse and on, directly, the free speech rights of those citizen-voters whose access to invited undocumented perspectives would be impaired.

Related, but certainly worthy of separate mention, is the role of the widely recognized free speech value of the pursuit of truth. ${ }^{49}$ There is no evidence that

45. See, e.g., supra note 44; see also SIR ERNEST BARKER, REFLECTIONS ON GOVERNMENT 412 (1942) ("Democracy must enlist the thought of the whole community in a process of discussion....").

46. Sullivan, 376 U.S. at 270.

47. See Cohen v. California, 403 U.S. 15, 21 (1971) (noting that "[t]hose in the Los Angeles courthouse could effectively avoid further bombardment of their sensibilities simply by averting their eyes" from the allegedly offensive language of a political message on defendant's jacket in court building).

48. Id.

49. The classic cite to the pursuit of truth as a purpose of freedom of speech is JOIN STUART MILL, ON LIBERTY 76-77 (Gertrude Himmelfarb ed, 1974) (1859). For a range of contemporary discussions of the pursuit of truth as a free speech value, see, for example, FREDERICK SCHAUER, FREE SPEECH: A PHILOSOPHICAL ENQUIRY 15 (1982); Greenawalt, supra note 33, at 130-33; William P. Marshall, In Defense of the Search for Truth as a First Amendment Justification, 30 GA. L. REV. 1, 1 (1995); Steven D. Smith, Skepticism, Tolerance, and Truth in the Theory of Free Expression, $60 \mathrm{~S}$. CAL. L. REv. 649, 655 (1987); Christopher T. Wonnell, Truth and the Marketplace of Ideas, 19 U.C. DAVIS L. REV. 669, 670 (1986) ("Historically, . . . one of the most important defenses of freedom of 
undocumented immigrants are widely incapable of contributing distinctively to the search for truth about immigration policy, in its experiential or its more objective dimensions, or for that matter, on any matter of public interest. But even this easilymet standard exceeds what is necessary to advance our thesis in this narrow respect. All our thesis requires is that some percentage of citizen-voters believe that undocumented willing speakers are capable at various times of usefully contributing to an ongoing or anticipated public discussion at any governmental level. Any more demanding standard, as noted above in connection with the free speech value of democracy, ${ }^{50}$ would violate the Court's clear desire in Cohen ${ }^{51}$ not to empower censorious majorities. ${ }^{52}$

\section{Do the EQUal Protection Rights of All PERSONS UnCONTROVERSIALly ADVANCE THE FREE SPEECH ARGUMENT?}

It is clearly established that the scope of both due process ${ }^{53}$ and equal protection $^{54}$ encompass not merely all citizens, but all "persons" within the

speech has been its alleged role in advancing the pursuit of truth.').

50. See supra notes $47-48$ and accompanying text.

51. See supra note 48 and accompanying text.

52. There are other arguably relevant free speech values, including those of self-realization and tolerance. See Brian Murchison, Speech and the Self-Realization Value, 33 Harv. C.R.-C.L. L. REv. 443, 445-46 (1998); Martin H. Redish, The Value of Free Speech, 130 U. PA. L. REV. 591, 593 (1982), and LeE C. BOlLINGER, THE TOlerANT SOCIETY: FreEDOM OF SPEECH AND EXTREMIST SPEECH IN AMERICA 9 (1986). But merely for the sake of the simplicity and reduced controversiality of the argument, we assume that focusing on these particular values as undergirding freedom of speech would add little weight to the arguments above, or else would be seen as biased in favor of pragmatic, if not formal, free speech rights for undocumented persons, in some question-begging way.

53. See, e.g., Mathews v. Diaz, 426 U.S. 67,78 (1976) (permitting distinctions among classes of resident aliens for Medicare benefits eligibility purposes; observing that simply because "all persons, aliens and citizens alike, are protected by the Due Process Clause does not lead to the further conclusion that all aliens are entitled to enjoy all the advantages of citizenship or, indeed, to the conclusion that all aliens must be placed in a single homogeneous legal classification"); Kim Ho Ma v. Ashcroft, 257 F.3d 1095, 1108-09 (9th Cir. 2001) (quoting Mathews, 426 U.S. at 77 (internal quotation marks omitted)). The court in Kim Ho Ma noted:

[T] here are literally millions of aliens within the jurisdiction of the United States. The Fifth Amendment, as well as the Fourteenth Amendment, protects every one of those persons from deprivation of life, liberty, or property without due process of law. Even one whose presence in this country is unlawful, involuntary, or transitory is entitled to that constitutional protection.

Id. If we say that undocumented persons have various property and liberty interests, perhapsincluding liberty of speech, protected as a matter of due process, we must presumably be able to specify the source or origin of such recognized interests. $C f$. Bd. of Regents v. Roth, 408 U.S. 564, 577 (1972) (for due process purposes, property interests created not by the Constitution itself, but "created and their dimensions ... defined by existing rules or understandings that stem from an 
jurisdiction. One might imagine, on this basis, that if undocumented immigrants were to count as "persons" within the jurisdiction, the Fourteenth Amendment due process clause, perhaps through the idea of "incorporation" of earlier amendments, ${ }^{56}$ the Fourteenth Amendment equal protection clause, and the Fifth Amendment due process clause or its equal protection "component" ${ }^{57}$ might uncontroversially smooth the path to free speech rights of undocumented persons as against state and federal actors.

One obstacle, at least of a formal nature, for such arguments is that the First Amendment does not clearly and unequivocally indicate the class of free speech right holders. ${ }^{58}$ By its terms, the First Amendment simply bars Congress from abridging an apparent institution referred to as "the freedom of speech." 59 The scope of protected speakers is not otherwise specified. The freedom of speech protected therein could be that of 'persons' or perhaps of 'the people., ${ }^{, 60}$ This unresolved uncertainty does not advance the case for the free speech rights of undocumented persons in an uncontroversial way.

Based on the text of the First Amendment, it is thus possible to argue that undocumented persons, either as an entirety, or those of only minimal or transient United States residency, do not fall within the scope of constitutionally protected speakers. It is difficult to imagine that the distinction between documented and undocumented aliens was especially meaningful, let alone important, in the historical

independent source such as state law").

54. See, e.g., Plyler v. Doe, 457 U.S. 202, 212-15 (1982) (regarding equal protection rights of undocumented immigrant children in the context of public school access); Sugarman v. Dougall, 413 U.S. 634, 641 (1973) ("It is established, of course, that an alien is entitled to the shelter of the Equal Protection Clause.") (citing, inter alia, Graham v. Richardson, 403 U.S. 365, 371 (1971); Yick Wo v. Hopkins, 118 U.S. 356, 369 (1886)).

55. For a survey of the scope of "persons," in various contexts, under the federal Constitution, see Roe v. Wade, 410 U.S. 113, 156-58 (1973).

56. For a crucial discussion of the selective incorporation of a variety of constitutional rights into the scope of the Fourteenth Amendment due process clause, and thus made binding against the states in favor of all Fourteenth Amendment "persons," see Duncan v. Louisiana, 391 U.S. 145, 14749 (1968).

57. For discussion, see United States v. Armstrong, 517 U.S. 456, 464 (1996) (claiming selective prosecution based on race); Bolling v. Sharpe, 347 U.S. 497, 500 (1954) (federal counterpart to state public school desegregation cases).

58. See U.S. CoNST. amend. I.

59. For discussion, see Mark P. Denbaux, The First Word of the First Amendment, $80 \mathrm{Nw}$. U.L. REV. 1156, 1156 (1986).

60. For discussion of possible meanings of the references to "the people" elsewhere in the First Amendment, as well in the Second, Fourth, Ninth, and Tenth Amendments, see United States v. Verdugo-Urquidez, 494 U.S. 259, 265, 266-67 (1990) (plurality opinion) (suggesting that "the people" generally refers to "a class of persons who are part of a national community or who have otherwise developed sufficient connection with this country to be considered part of that community"). 
adoption of the language of the First Amendment in general, or the free speech clause in particular. $^{61}$

Let us assume, though, that undocumented, along with documented, immigrants count as "persons" under the equal protection clause, as cases such as Plyler v. Doe $e^{62}$ evidently establish. From the premise that both documented and undocumented aliens are persons for equal protection or due process purposes, it still might be controversial to infer that undocumented persons, along with documented persons, should hold free speech rights. Some substantive argument to that effect would then still be necessary.

Such a substantive argument would be necessary because of the general principle that, for some purposes, it is constitutionally permissible to treat different classes of aliens differently, and to accord different rights to different classes of aliens. ${ }^{63}$ Certainly, there is case authority at least casually recognizing free speech rights for "aliens" as a general classification. ${ }^{64}$ But the leading cases recognizing free speech rights for aliens have, up to this point, apparently involved aliens who have entered the United States in some documented status. ${ }^{65}$

Certainly, an argument from the equal protection rights of undocumented persons to the free speech rights of such persons can be made under the logic of

61. Professor Gerald Neuman has taken issue with the idea that for the first century postIndependence, federal and state law typically placed only minimal limits on immigration. See Gerald L. Neuman, The Lost Century of American Immigration Low (1776-1875), 93 COLUM. L. REv. 1833, 1833-35 (1993). But Professor Neuman himself writes that " $[t]$ he myth of an era of unrestricted immigration to the United States is so widespread in the legal literature that authors cited to illustrate it need feel no individual embarrassment." Id. at 1835. Professor Neuman acknowledges that "[n]either Congress nor the states attempted to impose quantitative limits on immigration." Id. at 1834.

62. 457 U.S. 202, 215 (1982).

63. See, e.g., American-Arab Anti-Discrimination Comm. v. Reno, 70 F.3d 1045, 1063-64 (9th Cir. 1995) ("The Supreme Court has consistently distinguished between aliens in the United States and those seeking to enter from outside the country...."); Mathews v. Diaz, 426 U.S. 67, 78 (1976) ("The fact that all persons, aliens and citizens alike, are protected by the Due Process Clause does not lead to the further conclusion that all aliens ... must be placed in a single homogeneous legal classification."); Verdugo-Urquidez, 494 U.S. at 271 (quoting Kwong Hai Chew v. Colding, 344 U.S. 590, 596 (1953)) (distinguishing between lawfully admitted and non-lawfully admitted entrants for purposes of Bill of Rights protection).

64. See, e.g., Bridges v. Wixon, 326 U.S. 135, 148 (1945) (citing Bridges v. Califomia, 314 U.S. $252(1941))$.

65. Harry Bridges, the named party in the cases cited supra note 64 , was for many years a nationally prominent West Coast docks labor leader who, despite deportation litigation with an explicit political content, would not have been considered an undocumented immigrant. For discussion of a wide range of related topics, see the website of the University of Washington's Harry Bridges Center for Labor Studies, available at http://depts.washington.edu/pcls (last visited Dec. 25, 2009). Unsurprisingly, the Court in Wixon, 326 U.S. at 148, refers merely and without differentiation to "aliens." The more recent case of Verdugo-Urquidez, 494 U.S. at 271 , refers explicitly to the rights of "resident aliens" in Wixon. 
Plyler. Plyler recognizes the equal protection rights of undocumented students. ${ }^{66}$ The Court, after rejecting a strict scrutiny test in similar cases ${ }^{67}$ because of the alterability of undocumented status, ${ }^{68}$ appears to adopt, at least for the unique circumstances in Plyler, ${ }^{69}$ an especially rigorous balancing-oriented form of minimum scrutiny. ${ }^{70}$ This form of minimum scrutiny seems to require something like a "substantial" regulatory interest, and to allow for a certain resistance by reviewing courts to the state's evidence and reasoning. ${ }^{72}$ Presumably the unusual rigor of the equal protection review in Plyler largely reflects the sense that the practical stakes in these cases are unusually high, ${ }^{73}$ and a past of insufficient federal leadership on the issue. ${ }^{74}$

Thus, Plyler established meaningful equal protection rights for undocumented children, at least in the narrow and practically crucial context of access to public schools. $^{75}$ And at this point, it would thus be entirely reasonable to say that any attempt by a public school official to censor the speech of an undocumented student, on the grounds of that student's undocumented status, would inevitably raise an equal protection argument that implicated a right to speak.

The basic logic of this transition from an undocumented student's enforceable constitutional equal protection right to attend public school to some minimal degree of indirect free speech protection in school for that undocumented student seems clear enough. The undocumented student, under Plyler, has an enforceable constitutional equal protection right to attend an established public school system on basically equal terms with other students. ${ }^{76}$ Suppose two students, one undocumented and one not, were disciplined for distributing political literature on school grounds. As a matter of equal protection under Plyler, would we want to apply the standard Tinker ${ }^{77}$ free

66. See Plyler v. Doe, 457 U.S. 202, 211 (1982).

67. See id. at 219 n. $19,223$.

68. See id. at 220.

69. These circumstances would include the crucial practical, though not federal constitutional, status of a public school education, as well as the status of practically blameless undocumented children who might remain within the country as something of a permanent underclass if denied an education. See id. at 213, 221, 223-24.

70. See id. at 224,225 (referring to "an equal protection balance").

71. See id. at 224.

72. See the majority's "rebuttals" to the various state interest arguments, id. at 227-30.

73. See supra note 69.

74. See Plyer, 457 U.S. at 242 (Burger, C.J., dissenting) ("The Court makes no attempt to disguise that it is acting to make up for Congress' lack of 'effective leadership' in dealing with the serious national problems caused by the influx of uncountable millions ... across our borders.").

75. See id. at 215.

76. The right must be provided on equal terms, Brown v. Bd. of Educ., 347 U.S. 483, 493 (1954), despite the denial of a fundamental federal constitutional right to an education itself. San Antonio Indep. School Dist. v. Rodriguez, 411 U.S. 1, 35 (1973).

77. See Tinker v. Des Moines Indep. Cmty. Sch. Dist., 393 U.S. 503, 512-13 (1969) (permitting restriction of public school students' political speech on a substantial showing of actual or 
speech test in the case of the documented student, but no free speech test at all in the case of the otherwise similarly situated undocumented student? Might granting Tinker protection to one student's speech, but lesser or no protection to the undocumented student's speech, on grounds of undocumented status, violate the undocumented student's equal protection rights under Plyler? Must we read Plyler as recognizing attendance rights for undocumented students, but absolutely no free speech rights while duly enrolled?

Even though this argument seems sound, it cannot not be herein relied upon because it is controversial how far the argument actually goes. Plyler, after all, may rest at least in part on the predictably disastrous consequences of large numbers of unschooled adults. $^{78}$ It would be less plausible to predict disastrous consequences if undocumented student speech rights were determined solely by state statute or local rule, rather than by the First Amendment. Some might well read Plyler to require only minimum scrutiny equal protection in the case of restrictions on the public school speech of undocumented students. Or perhaps Plyler should be read to protect undocumented students' speech rights only where the students' ability to attend school is implicated.

Even if we read Plyler, sensibly, to require something like the Tinker free speech test for undocumented students where it is similarly applied to documented students, it remains controversial how far Plyler's equal protection rights should be extended to undocumented persons generally in various non-school contexts. Our approach, by contrast, is admittedly indirect. But our approach does have the advantage of a less controversial and more robust appeal to the free speech rights, as listeners, of citizenvoters. It is difficult to imagine courts' generally concluding that the free speech rights of citizen-voters who wish to hear undocumented speakers should evoke only minimum scrutiny in their defense. ${ }^{79}$ For these reasons, we have thus chosen not to place much reliance on Plyler's equal protection logic to generally validate undocumented free speech rights.

\section{CONCLUSION}

The uncontroversial free speech rights of individual citizen-voters, as willing potential listeners to a range of potentially willing undocumented speakers on a plethora of subjects, imply pragmatic free speech rights to undocumented speakers. What, though, are the distinctive limits of such pragmatic free speech rights?

For one thing, if we assume a settled immigration law, the free speech rights of citizen-voters, as individuals, cannot realistically be expected to trump any limitation on the immediate physical presence of any willing speaker from anywhere around the

likely disruption, disturbance, disorder, or violation of unspecified rights of others).

78. See supra note 69 and accompanying text.

79. Consider, for example, the more demanding tests variously applied in the case of listener, viewer, or reader rights in the cases cited supra note 25. 
world ${ }^{80}$ A particular citizen's desire to hear a willing speaker from a foreign country, in face-to-face conversation, will, of course, not typically overturn otherwise valid immigration law.

Additionally, any approach, such as ours, that focuses on undocumented speech communication directly or indirectly with citizens-voters, will leave other sorts of valuable speech by undocumented persons protected only on more complex grounds, or only through the separate constitutional protection of due process and against unreasonable searches and seizures. ${ }^{81}$ What of the free speech status of, say, notes taken by an undocumented person? Private conversations between and among undocumented persons, as well as materials such as computer files, phone records and diary entries by undocumented persons, could be protected from unreasonable searches and seizures, or sometimes more directly as preparatory to later direct or indirect discussion with one or more citizen-voters. ${ }^{82}$

We may conclude by noting explicitly that we have typically assumed throughout, for the sake of simplifying the argument, that all undocumented persons can be instantly and uncontroversially recognized as "undocumented" for free speech purposes. In many cases, however, a free speech argument may crystallize before there is any sort of administrative or judicial determination, let alone a final judgment, that the speaker in question is in any sense undocumented. ${ }^{83}$ Often, the government official restricting the speech at issue will have no special competence or jurisdiction

80. See generally Title 8, Chapter 12 of the United States Code on immigration priorities and procedures. We need have no quarrel here with the actual current scope of what is known as the "plenary power" doctrine in immigration law. See generally T. ALEXANDER ALEINIKOFF, Semblances of Sovereignty: The Constitution, the StaTe, AND AMERICAN CtTIZENSHIP Ch. 7 (2002); Stephen H. Legomsky, Ten More Years of Plenary Power: Immigration, Congress, and the Courts, 22 Hastings CONST. L.Q. 925 (1995); Maria Pabón López, A Tale of Two Systems: Analyzing the Theatment of Noncitizen Families in State Family Law Systems and Under the Immigration Law System, 11 HARV. LATINO L. REV. 229, 238 (2008). For our purposes, we may grant an unfettered congressional power to legally exclude aliens outside the United States from physically entering the United States, or to condition their entry upon constitutionally permissible grounds related to speech. See, e.g., Kleindienst v. Mandel, 408 U.S. 753, 756-66 (1972); W. Aaron Vandiver, Checking Ideas at the Border: Evaluating the Possible Renewal of Ideological Exclusion, 55 EMORY L.J. 751, 751 (2006). Free speech law should presumably not drive basic decisions as to who should be officially allowed to enter the United States. See supra note 23 and accompanying text. But the plenary power doctrine does not deny all enforceable federal constitutional rights, formally or pragmatically, to undocumented persons within the United States. See, e.g., the discussion of Plyler, supra Part IV.

81. For discussion, see United States v. Verdugo-Urquidez, 494 U.S. 259, 271-72 (1990); Kim Ho Ma v. Ashcroft, 257 F.3d 1095, 1107-08 (9th Cir. 2001).

82. For a case of protected speech involving a private drawing, sketched at home and inadvertently brought to school by another person, see Porter v. Ascension Parish Sch. Bd., 393 F.3d 608,611 (5th Cir. 2004).

83. See, e.g., Lopez v. Town of Cave Creek, Ariz., 559 F. Supp. 2d 1030, 1031 (D. Ariz. 2008) (ordinance prohibiting roadside solicitation of employment challenged on free speech grounds by numbers of "day laborers," with no reference in the case to any undocumented workers). 
over immigration matters. ${ }^{84}$ The undocumented status we have been assuming throughout must not be casually assumed by officials who may be inclined to restrict speech. In this respect, much of this Essay has in effect conservatively assumed that justifying restrictions on the speech of undocumented persons is easier than it actually is.

84. Nor will it always be obvious to law enforcement officials whether the speech involved is itself illegal under state or federal law, even assuming the speaker to be undocumented. For discussion, see, for example, Comite de Jomaleros de Redondo Beach v. City of Redondo Beach, 475 F. Supp. 2d 952, 957 (C.D. Cal. 2006); Kathryn Nicole Lewis, Streets of Wrath: The Constitutionality of the Town of Jupiter's Non-Solicitation Ondinance, 37 STETSON L. REV. 471, 50001 (2008). Logically, if undocumented persons have no state or federal free speech rights, it should not be necessary to hold any hearing or apply any test when any concededly undocumented person exclusively raises any free speech claim or defense. Any judicial temptation to ever hold such a hearing, it is fair to imagine, may bespeak a judicial sense that such a rule is intuitively objectionable. 
